\title{
PEMANFAATAN PESTISIDA NABATI PADA PENGENDALIAN HAMA PLUTELLA XYLOSTELLA TANAMAN SAWI (Brassica juncea L.) MENUJU PERTANIAN RAMAH LINGKUNGAN
}

\section{UTILIZATION OF PESTICIDES VEGETABLE ON PEST CONTROL PLUTELLA XYLOSTELLA ON PLANTS MUSTARD GREENS (Brassica juncea L.) TOWARDS SUSTAINABLE AGRICULTURE}

\author{
Suhartini*, IGP Suryadarma dan Budiwari \\ Jurusan Pendidikan Biologi, FMIPA, Universitas Negeri Yogyakarta \\ *email: suhartini@uny.ac.id
}

Diterima 22 Februari 2017, disetujui 17 Maret 2017

\begin{abstract}
Abstrak
Penggunaan pestisida kimia telah banyak memberikan dampak negative, maka dari itu penelitian ini bertujuan untuk mengetahui efektivitas dari ekstrak pestisida nabati yaitu daun tembakau, tapak liman, daun kayu kuning dan daun sirih hijau terhadap mortalitas hama Plutella Xylostella pada tanaman sawi (Brassica juncea L.) berat basah sawi dan kerusakan daun sawi. Penelitian ini menggunakan Rancangan Acak Lengkap dengan perlakuan jenis tanaman sebagai pestisida Nabati. Perlakuan yang digunakan ada 6 macam yaitu kontrol negatif (P0), daun tembakau (P1), tapak liman (P2), daun kayu kuning (P3), daun sirih hijau (P4) dan pestisida kimia sebagai kontrol positif (P5) dengan masing-masing kadar $10 \%$. Parameter yang diamati adalah mortalitas hama, berat basah sawi dan tingkat kerusakan daun sawi. Analisis dilakukan dengan anova satu arah. Hasil penelitian menunjukkan ekstrak daun yang paling berpengaruh pada mortalitas Plutella xylostella secara berurutan adalah tembakau, daun sirih, daun kayu kuning dan tapak liman. Sedangkan pada berat basah sawi (brassica juncea 1.) secara berurutan daun kayu kuning, daun sirih hijau, daun tapak liman dan daun tembakau. Sementara terhadap tingkat kerusakan daun sawi mulai yang paling kecil rusaknya secara berurutan adalah daun sirih hijau, daun tembakau, tapak liman dan daun kayu kuning.
\end{abstract}

Kata Kunci: Pestisida Nabati, ekstrak, Plutella xylostella, mortalitas, sawi (Brassica juncea)

\begin{abstract}
The use of chemical pesticides has many negative impacts. This study aims to determine the effectiveness of the vegetative pesticide extract of tobacco leaves, tapak liman, daun kayu kuning and green betel leaves towards the mortality of Plutella Xylostella in mustard plants (Brassica juncea L.) including the water content of mustard and damage to the mustard leaves. This research project used Complete Randomized Design with the treatment of plant species as a vegetative pesticide. The treatments used were 6 kinds of negative control (P0), tobacco leaf $(P 1)$, liman (P2), daun kayu kuning (P3), green betel leaves (P4) and chemical pesticide as positive control (P5) respectively 10\%. The parameters observed were mortality of pests, water content of mustards and damage level of mustard leaves. The analysis was conducted by applying one way anova. The results sequentially showed that the most influential leaf extract on mortality of Plutella xylostella were tobacco, green betel leaf, daun kayu kuning and tapak liman. The water content level of mustard (brassica juncea l.) from the least to the highest was daun kayu kuning, green betel leaf, daun tapak liman and tobacco leaf. Meanwhile the least level of damage to the mustard leaves in sequence was the leaves of green betel leaf, tobacco leaf, daun tapak liman and daun kayu kuning.
\end{abstract}

Keywords: Pesticides Vegetable, extract, Plutella xylostella, mortality, Brassica juncea

\section{Pendahuluan}

Pembangunan di bidang pertanian sampai saat ini masih menghadapi masalah antara lain pencemaran lingkungan, rendahnya kualitas bahan tanaman, rendahnya produktivitas tanaman, serangan organisme pengganggu tanaman (OPT) dan residu pestisida pada produk pertanian. Banyaknya dampak negatif yang ditimbulkan akibat penggunaan pestisida kimia, mendorong 
pemerintah untuk mengalihkan kepada pemanfaatan jenis-jenis pestisida yang aman bagi lingkungan. Kebijakan ini juga sebagai konsekuensi implementasi dari pertanian yang berwawasan lingkungan dalam pembangunan yang berkelanjutan. Berkaitan dengan hal tersebut maka pemerintah Indonesia mengeluarkan kebijakan nasional dalam perlindungan tanaman, untuk menggalakkan program Pengendalian Hama Terpadu (PHT) dengan mengutamakan pemanfaatan agens pengendalian Nabati atau biopestisida sebagai komponen utama dalam sistem PHT yang dituangkan dalam Peraturan Pemerintah No. 6 tahun 1995. Hal ini dipilih karena pemanfaatan agens pengendalian hayati atau biopestisida dalam pengelolaan hama dan penyakit dapat memberikan hasil yang optimal dan relatif aman bagi makhluk hidup dan lingkungan.

Untuk menghasilkan produk pertanian yang mencukupi maka setiap gangguan hama dan penyakit $(\mathrm{OPT}=$ Organisma Pengganggu Tanaman) harus dilakukan secara bijaksana, apalagi pada era pertanian yang sehat (back to nature) yang lebih mementingkan produk berkualitas dan bebas dari cemaran, baik hayati maupun kimia. Syakir, 2011 menjelaskan bahwa produk pertanian yang sehat dan ramah lingkungan sudah merupakan tuntunan pasar global (AFTA, APEC, dan WTO), dengan label ramah lingkungan (eco-labeling attributes), bernutrisi tinggi (nutritional attributes), dan aman dikonsumsi (food safety attributes)[1].

Sementara itu sawi merupakan jenis sayuran yang disukai oleh masyarakat Indonesia, mulai dari golongan masyarakat kelas bawah sampai golongan masyarakat kelas atas. Sawi adalah bahan makanan nabati yang biasa dikonsumsi oleh masyarakat Indonesia. Kandungan Zat Gizi Sawi dalam $100 \mathrm{~g}$ adalah sebagai berikut:

Tabel 1. Kandungan gizi sawi

\begin{tabular}{cc}
\hline Zat Gizi & Sawi \\
\hline Protein $(\mathrm{g})$ & 2,3 \\
\hline Lemak $(\mathrm{g})$ & 0,3 \\
\hline Karbohidrat $(\mathrm{g})$ & 4,0 \\
\hline $\mathrm{Ca}(\mathrm{mg})$ & 220,0 \\
\hline $\mathrm{P}(\mathrm{mg})$ & 38,0 \\
\hline $\mathrm{Fe}(\mathrm{mg})$ & 2,9 \\
\hline Vitamin A (mg) & $1.940,0$ \\
\hline Vitamin B $(\mathrm{mg})$ & 0,09 \\
\hline Vitamin C $(\mathrm{mg})$ & 102 \\
\hline
\end{tabular}

Sumber: Direktorat Gizi Departmen Kesehatan RI, 2001
Menurut BPS, 2011, konsumsi sawi dari tahun ke tahun mengalami peningkatan, dan pada tahun 2011 kebutuhan sawi mencapai 1,2 ton per minggu, angka ini sangat tinggi jika dibandingkan dengan sayuran lainnya seperti mentimun, labu siang, kangkung dan kacang panjang. Tanaman sawi juga tidak terlepas dari organisme Pengganggu Tanaman (OPT), yaitu Plutella xylostella. Hama ini dapat menurunkan hasil panen 30-40\%, bahkan pada beberapa kasus dapat mengakibatkan gagal panen. Pada tanaman hortikultura, biaya produksi untuk pengendalian hama dapat mencapai $40 \%$, bahkan bisa lebih [2]. Maka dari itu alternatif pemanfaatan pestisida nabati yang berasal dari tanaman sangat penting dalam pengendalian hayati untuk menuju pertanian yang berwawasan lingkungan. Pestisida Nabati sebenarnya merupakan kearifan lokal bangsa Indonesia, karena banyak masyarakat yang sudah mengetahui jenis tanaman yang dapat digunakan untuk mengendalikan hama tanaman, namun kurang dikembangkan, sementara Indonesia kaya akan keanekaragaman hayati.

Indonesia merupakan negara yang memiliki keanekaragaman hayati terluas kedua di dunia setelah Brasil. Tumbuhan merupakan gudang berbagai senyawa kimia yang kaya akan kandungan bahan aktif, antara lain produk metabolit sekunder (secondary metabolic products). Kelompok senyawa ini berperan penting dalam proses berinteraksi atau berkompetisi, termasuk melindungi diri dari gangguan pesaingnya [2]. Produk metabolit sekunder dapat dimanfaatkan sebagai bahan aktif pestisida nabati [3];[4]. Maka dari itu penting dikembangkan pemanfaatan berbagai jenis tanaman sebagai pestisida Nabati untuk menuju pertanian yang ramah lingkungan dan pembangunan yang berkelanjutan. Banyaknya tanaman yang mempunyai zat aktif sebagai pestisida hayati, maka perlu diketahui jenis tanaman apakah yang efektif untuk pengendalian hama Plutella stylostella pada tanaman sawi sehingga dapat mewujudkan pertanian yang ramah lingkungan. Untuk itu maka penelitian ini bertujuan untuk mengetahui efektivitas dari larutan pestisida Nabati yaitu daun tembakau, tapak liman, daun sirih hijau dan daun kayu kuning terhadap mortalitas hama Plutella Xylostella pada tanaman sawi (Brassica juncea L.). Melalui penelitian ini diharapkan dapat memberikan informasi jenisjenis tanaman yang efektif sebagai bahan penghasil pestisida nabati dan membantu masyarakat dalam mengenali dan memanfaatkan jenis-jenis tanaman untuk pengendalian hama tanaman sawi. 


\section{Metode Penelitian}

Penelitian dilakukan di kebun dan laboratorium Biologi, FMIPA, Universitas Negeri Yogyakarta, dimulai pertenganhan bulan Mei sampai bulan Oktober 2016. Adapun bahan yang, digunakan adalah daun tembakau, tapak liman, daun sirih dan daun kayu kuning yang diambil di daerah Istimewa Yogyakarta. Hama Plutella xylostella diambil dari TOM (Tani Organik Merapi) di Cangkringan dan Dusun Purworejo, Hargobinangun, Pakem serta benih sawi. Alat yang digunakan adalah pot, sprayer, toples, timbangan, blender, batang kayu, botol plastik, nampan, karung dan air.

\section{Variabel}

Variabel bebas dalam penelitian ini adalah jenis tanaman (tembakau, tapak liman, sirih dan daun kayu kuning), kontrol positif (pestisida) dan kontrol negatif (tanpa perlakuan). Sedangkan Variabel terikat meliputi mortalitas Plutela xylostella , berat basah sawi dan tingkat kerusakan daun sawi

\section{Rancangan Penelitian dan Analisis Data}

Penelitian ini menggunakan Rancangan Acak Lengkap yang terdiri dari empat perlakuan jenis tanaman sebagai pestisida nabati, satu kontrol negatif (tanpa perlakuan) dan satu kontrol positif (menggunakan pestisida kimia). Kombinasi perlakuannya adalah: $\mathrm{P} 0=$ kontrol negatif,; $\mathrm{P} 1=$ daun tembakau; P2 = daun tapak liman; P3 = daun kayu kuning; $\mathrm{P} 4=$ daun sirih hijau dan $\mathrm{P} 5=$ kontrol positif (pestisida kimia). Masing-masing perlakuan diulang lima kali. Data yang diperolah dianalisis menggunakan analisis ragam (ANOVA) dan dilanjutkan dengan uji LSD dengan taraf nyata $5 \%$ untuk mengetahui efek perlakuan

\section{Pelaksanaan Penelitian}

Pembuatan larutan pestisida nabati dari daun tembakau, tapak liman, daun kayu kuning dan daun sirih hijau.. Berdasarkan metode pada penelitian [5], maka digunakan konsentrasi $10 \%$ atau 100 gram/1 liter air. Bagian daun tembakau, tapak liman, daun kayu kuning dan daun sirih hijau masing-masing sebanyak 100 gram dicuci kemudian ditambahkan air sebanyak 1 liter dan diblender. Setelah itu disaring agar tidak terdapat kotoran yang menyumbat sprayer kemudian direndam selama 24 jam.

Penyiapan larva Plutella xylostella sebagai bahan uji diambil dari Sawah di dusun Purwareja,
Hargobinangun Pakem yang berada di bawah pengawasan Dinas Pertanian Kabupaten Sleman, dan di TOM (Tani Organik Merapi), Cangkringan, Sleman, selanjutnya dipelihara di laboratorium biologi. Jenis larva yang diambil untuk penelitian adalah jenis larva yang telah mencapai tahap instar 3.

Penyiapan benih Sawi. Benih Sawi dibeli di Toko Pertanian (Toko Tani Maju) lalu dilakukan pembibitan dengan menggunakan tray semai di kebun biologi, FMIPA, UNY . Setelah bibit sawi memiliki daun tiga lembar (berumur 3 minggu), maka bibit sawi dipindahkan ke pot. Bibit Sawi dipilih sebanyak 30 individu untuk digunakan penelitian. Tanaman Sawi yang dijadikan untuk sampel (disemprot dengan obat nabati) berumur 21 hari setelah tanam (HST).

Ulat yang telah diperoleh (mencapai tahap instar 3) kemudian dimasukkan satu persatu pada tanaman sawi yang telah berusia 21 hari setelah tanam. Untuk setiap tanaman diberikan ulat sebanyak 5 larva. Aplikasi ulat ini dilakukan pada sore hari karena di sore hari ulat aktif menyerang tanaman sawi. Menurut Lubis (2004) sepuluh larva tiap tanaman merupakan ambang ekonomi pada tanaman sayuran daun termasuk sawi. Namun demikian karena jumlah ulat yang diperoleh terbatas, maka setiap tanaman hanya diberikan 5 larva

Larva dibiarkan selama satu hari tanpa pemberian pestisida nabati. Setelah masuk hari kedua, aplikasi penyemprotan pestisida nabati dilakukan. Setelah itu diamati setiap gejala yang timbul dari larva tersebut (mati atau menjadi pupa). Penyemprotan pestisida nabati diulang lagi satu hari setelah pengamatan, selanjutnya 1 hari setelah penyemprotan dilakukan pengamatan lagi untuk menghitung jumlah Plutella yang mati atau menjadi pupa, demikian seterusnya dilakukan penyemprotan sampai 3 kali.

Panen . Sawi dapat dipanen antara 28-32 hari dengan ciri sawi telah memanjang agak membulat dan daun cukup lebar. Sawi dibersihkan selanjutnya ditimbang untuk memperoleh bobot basah tanaman.

\section{Parameter yang Diamati}

1) Mortalitas hama.

Menurut Amalia (2004), persentase hama yang mati dihitung dari jumlah ulat yang mati pada setiap perlakuan. Persentase dapat dihitung dengan rumus : (ulat/larva mati: total ulat/larva) x $100 \%$. Pengamatan dilakukan setiap hari dengan melihat dan memperhatikan ulat yang mati selama kurun 
waktu 3 kali aplikasi pestisida nabati atau setelah aplikasi ulat dalam tanaman sawi tiap pot dan penyemprotan pestisida nabati serta diamati tingkat kerusakan daun sawi

\section{2) Berat basah sawi}

Penimbangan dilakukan pada setiap sawi pada masing-masing perlakuan. Sawi ditimbang dengan menggunakan timbangan digital dengan satuan gram. Setiap hasil berat dari masing - masing perlakuan dicatat dalam bentuk tabel. Penimbangan dilakukan langsung setelah tanaman sawi dipanen.

\section{Hasil dan Pembahasan}

Banyak tanaman yang dapat dimanfaatkan sebagai pestisida nabati, dalam penelitian ini digunakan daun tembakau, tapak liman, daun kayu kuning dan daun sirih hijau. Berdasarkan hasil penelitian mengenai pemanfaatan pestisida nabati pada pengendalian hama Plutella Xylostella tanaman sawi (Brassica juncea L.) menuju pertanian ramah lingkungan dapat diuraikan sebagai berikut.

\section{A. Pengaruh Ekstrak Daun Tembakau, Tapak Liman, Daun Kayu Kuning Daun Sirih dan Pestisida Kimia Terhadap Mortalitas Larva Instar III Plutella xylostella}

Hasil pengamatan dari tiga kali aplikasi ekstrak daun tembakau, tapak liman, daun kayu kuning dan daun sirih terhadap mortalitas larva instar 3 Plutella xylostella dapat dilihat pada Lampiran 1.

Hasil pengamatan menunjukkan a jumlah mortalitas (kematian) larva instar III Plutella xylostella yang menggunakan pestisida kimia pada penyemprotan pertama adalah $100 \%$, sehingga larva instar III Plutella xylostella dengan sekali penyemprotan sudah mati semua. Pada kontrol (penyemprotan dengan air), kematian setelah penyemprotan 1 adalah $12 \%$, setelah penyemprotan ke 2 ada $28 \%$ dan setelah penyemprotan ke 3 sebesar $60 \%$. Sementara itu pada penggunaan daun tanaman tembakau, tapak liman, daun kuning dan daun sirih hijau sebagai pestisida nabati memberikan hasil yang berbeda beda, dimana yang mengalami kematian terbesar secara berurutan pada penyemprotan pertama adalah tembakau, daun kuning, tapak liman dan terkecil daun sirih hijau. Sementara itu pada penyemprotan kedua yang mengalami kematian terbesar secara berturutan adalah daun sirih, tapak liman, tembakau dan daun kuning. Hal ini memberikan indikasi bahwa dengan daun sirih pada penyemprotan pertama, plutella xylostella tidak mati tetapi mengalami percepatan menjadi pupa sehingga tidak dapat aktif makan daun lagi.

Berdasarkan hasil perhitungan pada Tabel 2 dapat dijelaskan bahwa dari 6 perlakuan (kontrol, daun tembakau, tapak liman, daun kayu kuning dan daun sirih hijau) diperoleh nilai signifikansi 0,000 yang berarti terdapat perbedaan yang nyata antar perlakuan. Untuk mengetahui perlakuan yang mana yang berbeda maka dapat dilihat pada Lampiran 2 .

Tabel 2. Hasil Analisis statistik Mortalitas Plutella xylostella Pada Penyemprotan Pertama dengan air (kontrol), daun tembakau, tapak liman, daun kayu kuning, daun sirih hijau dan pestisida kimia

\begin{tabular}{|c|c|c|c|c|c|}
\hline & $\begin{array}{c}\text { Sum of } \\
\text { Square } \\
s\end{array}$ & df & $\begin{array}{l}\text { Mean } \\
\text { Squar } \\
\text { e }\end{array}$ & $F$ & Sig. \\
\hline $\begin{array}{l}\text { Between } \\
\text { Groups }\end{array}$ & 78,800 & 5 & $\begin{array}{r}15,76 \\
0\end{array}$ & $\begin{array}{r}20,55 \\
7\end{array}$ & ,000 \\
\hline $\begin{array}{l}\text { Within } \\
\text { Groups }\end{array}$ & 18,400 & 24 & ,767 & & \\
\hline Total & 97,200 & 29 & & & \\
\hline
\end{tabular}


Tabel 3. Hasil Analisis statistik Mortalitas Plutella xylostella Pada Penyemprotan Kedua dengan air (kontrol), daun tembakau, tapak liman, daun kayu kuning dan daun sirih hijau

\begin{tabular}{lrrrrrr}
\hline & $\begin{array}{c}\text { Sum of } \\
\text { Squares }\end{array}$ & df & $\begin{array}{c}\text { Mean } \\
\text { Square }\end{array}$ & F & Sig. \\
\hline $\begin{array}{l}\text { Between } \\
\text { Groups }\end{array}$ & 5,040 & 4 & 1,260 &, 496 &, 739 \\
$\begin{array}{l}\text { Within } \\
\text { Groups }\end{array}$ & 50,800 & 20 & 2,540 & & \\
Total & 55,840 & 24 & & \\
\hline
\end{tabular}

Tabel 4. Hasil Analisis statistik Mortalitas Plutella xylostella Pada Penyemprotan Ketiga dengan air (kontrol), daun tembakau, tapak liman, daun kayu kuning dan daun sirih hijau

\begin{tabular}{lrrrrrr}
\hline & $\begin{array}{c}\text { Sum of } \\
\text { Squares }\end{array}$ & df & $\begin{array}{c}\text { Mean } \\
\text { Square }\end{array}$ & F & Sig. \\
\hline $\begin{array}{l}\text { Between } \\
\text { Groups } \\
\begin{array}{l}\text { Within } \\
\text { Groups }\end{array}\end{array}$ & 4,160 & 4 & 1,040 &, 642 &, 639 \\
Total & 32,400 & 20 & 1,620 & & \\
\hline
\end{tabular}

Dari Lampiran 2 dapat diketahui bahwa perlakuan yang memberikan perbedaan mortalitas Plutella stylostella secara nyata hanya terjadi antara pestisida kimia dengan kontrol dan semua perlakuan pestisida nabati (daun tembakau, tapak liman, daun kayu kuning, dan daun sirih), sementara antar kontrol dengan perlakuan pestisida nabati dan antara perlakuan pestisida nabati sendiri semua tidak ada perbedaan yang nyata $\mathrm{P}>0,05$. Dari perlakuan-perlakuan pestisida nabati tersebut yang memberikan nilai terkecil adalah daun tembakau dan daun sirih dengan nilai 0,289 yang masih berada di bawah 0,05 atau tetap tidak memberikan beda nyata. Selanjutnya pada penyembrotan kedua dihitung tanpa menyertakan perlakuan pestisida kimia karena larva Plutella stylostella semua sudah mati (mortalitas semua sudah 0) dapat dilihat pada tabel 3.

Berdasarkan perhitungan yang tertera pada Tabel 3 diketahui bahwa antara kontrol dan perlakuan pestisida nabati (daun tembakau, tapak liman, daun kayu kuning, dan daun sirih) maupun antar perlakuan sendiri diperoleh nilai signifikasi $\mathrm{P}$ sebesar 0,739>0,05 yang berarti tidak terdapat perbedaan mortalitas Plutella stylostella antara perlakuan satu dengan yang lain maupun antara perlakuan pestisida nabati dengan kontrol. Selanjutnya untuk hasil perhitungan analisis statistik pada penyemprotan ketiga dapat dilihat pada tabel 4.

Berdasarkan perhitungan yang tertera pada Tabel 4 dapat juga diketahui bahwa antara kontrol dan perlakuan pestisida nabati (daun tembakau, tapak liman, daun kayu kuning, dan daun sirih) maupun antar perlakuan sendiri diperoleh nilai signifikasi $\mathrm{P}$ sebesar 0,639>0,05 yang berarti tidak terdapat perbedaan mortalitas Plutella stylostella antara perlakuan satu dengan yang lain maupun antara perlakuan pestisida nabati dengan kontrol.

\section{B. Pengaruh Ekstrak Daun Tembakau, Tapak Liman, Daun Kayu Kuning Daun Sirih dan Pestisida Kimia Terhadap Berat Basah Sawi ((Brassica juncea L.)}

Ekstrak daun Tembakau, Tapak Liman, Daun Kayu Kuning Daun Sirih dan Pestisida Kimia yang disemprotkan pada daun sawi jelas akan mempengaruhi kemampuan Plutella stylostella dalam memakan daun sawi sehingga akhirnya akan tampak dalam Berat Basah Sawi ((Brassica juncea L.) seperti dapat dilihat pada tabel 5 . 
Berdasarkan tabel 5 dapat diketahui bahwa pestisida nabati yang mampu memberikan penambahan berat sawi adalah daun kayu kuning, sementara pada tiga perlakuan yang lain justru menghasilkan berat basah sawi yang lebih kecil dari kontrol. Hal ini disebabkan karena pada penggunaan pestisida nabati, daun tanaman menjadi rusak dan rebah sehingga menjadi busuk, karena Plutella xylostella menyerang pada pangkal daun sawi. Untuk tanaman yang disemprot menggunakan pestisida nabati maka memberikan nilai berat yang paling tinggi.. Adapun hasil analisis statistiknya dapat dilihat pada tabel 6 sebagai berikut:

Berdasarkan perhitungan yang tertera pada Tabel 6 dapat diketahui bahwa antara kontrol dan perlakuan pestisida nabati (daun tembakau, tapak liman, daun kayu kuning, dan daun sirih) dan dengan pestisida kimia maupun antar perlakuan sendiri diperoleh nilai signifikasi P sebesar $0,810>$ 0,05 yang berarti tidak terdapat perbedaan berat basah sawi ((Brassica juncea L.) antara perlakuan satu dengan yang lain maupun antara perlakuan pestisida nabati, kontrol dan dengan pestisida kimia.

Tabel 5. Berat basah sawi (Brassica juncea L.) pada perlakuan dengan pestisida nabati pada saat panen

\begin{tabular}{ccccc}
\hline No. & Nama Tanaman & \multicolumn{3}{c}{ Berat basah sawi (Brassica juncea L.) } \\
\hline & Kontrol & Konsentrasi 10 \% & Pestisida Kimia \\
\hline 1 & Tembakau & 54,72 & 27,76 & 70,64 \\
\hline 2 & Tapak Liman & 54,76 & 35 & 70,64 \\
\hline 3 & $\begin{array}{c}\text { Daun Kayu } \\
\text { Kuning }\end{array}$ & 54,72 & 63,2 & 70,64 \\
\hline 4 & Daun Sirih Hijau & 54,72 & 47,17 & 70,64 \\
\hline
\end{tabular}

Tabel 6. Hasil Analisis statistik Berat Basah Sawi (Brassica juncea L.) yang dipanen setelah Disemprot dengan air (kontrol), daun tembakau, tapak liman, daun kayu kuning, daun sirih hijau dan pestisida kimia

\begin{tabular}{lccccc}
\hline & Sum of Squares & df & Square & F & Sig. \\
\hline $\begin{array}{l}\text { Between } \\
\text { Groups }\end{array}$ & 240.456 & 3 & 80.152 & .322 & .810 \\
\hline $\begin{array}{l}\text { Within } \\
\text { Groups }\end{array}$ & 1991.172 & 8 & 248.897 & & \\
\hline Total & 2231.628 & 11 & & \\
\hline
\end{tabular}

Tabel 7. Prosentase tingkat kerusakan daun sawi (Brassica juncea L.) Pada Berbagai Perlakuan Pestisida Nabati

\begin{tabular}{llccc}
\hline No. & Nama Tanaman & \multicolumn{3}{c}{ Berat basah sawi } \\
\hline & & Kontrol & Konsen-trasi $10 \%$ & Pestisida Kimia \\
\hline 1 & Tembakau & 54,72 & 27,76 & 70,64 \\
\hline 2 & Tapak Liman & 54,76 & 35 & 70,64 \\
\hline 3 & Daun Kayu Kuning & 54,72 & 63,2 & 70,64 \\
\hline 4 & Daun Sirih Hijau & 54,72 & 47,17 & 70,64 \\
\hline
\end{tabular}


Hal ini disebabkan karena hampir semua perlakuan dan kontrol pada pangkal batang yang diberikan larva Plutella Stylostella rusak, sehingga daun menjadi busuk, kecuali pada tanaman yang disemprot dengan pestisida kimia memberikan hasil yang bagus karena Plutella Stylostella pada penyemprotan pertama langsung mati semua.

\section{Pengaruh Ekstrak Daun Tembakau, Tapak Liman, Daun Kayu Kuning Daun Sirih dan Pestisida Kimia Terhadap Tingkat Kerusakan Daun Sawi (Brassica juncea L.)}

Berdasarkan tingkat kerusakan daun yang diamati dari keutuhan daun dan keberadaan lubanglubang yang ada pada daun maka daun yang disemprot dengan pestisida kimiawi kerusakannya lebih sedikit $(11,09 \%)$ dibandingkan yang kontrol $(32,2 \%)$ maupun yang menggunakan perlakuan pestisida nabati. Untuk perlakuan pestisida nabati sendiri yang memberikan tingkat kerusakan daun paling kecil adalah daun sirih hijau $(19,25 \%)$, daun tembakau $(19,71 \%)$, tapak liman $(34,81 \%)$ dan daun kayu kuning $(35 \%)$. Kerusakan daun erat kaitannya dengan kemampuan larva Plutella xylostella untuk memakan daun sawi yang telah disemprot dengan pestisida nabati tersebut. Sementara itu kemampuan makan Plutella xylostella erat kaitannya dengan zat aktif yang terkandung pada daun yang telah disemprot dengan pestisida nabati tersebut. Kandungan zat aktif yang ada pada daun sirih hijau adalah eugenol, methyl eugenol, karvakrol, kavikol, alil katekol, kavibetol, sineol, estragol), karoten, tiamin, riboflavin, asam nikotinat, vitamin $\mathrm{C}$, tanin, gula, pati, dan asam amino. Pada daun tembakau mengandung alkaloida, saponin, flafonoida dan polifenol, pada tapak liman mengandung alkaloida, flafonoida dan polifenol[6] dan pada daun kuning mengandung saponin, flavonoida, dan tanin [7]. Molekul biotoksin yang aktif berperan sebagai biosida dapat digolongkan dalam golongan alkaloid (nikotin, nornikotin, anabasin, solanin, atropin dll.) dan golongan metabolit sekunder (pyrethrum kompleks, pirethroid sintetik, rotenon dan rotenoid, quassin, ryanin, phytolaccin, azadirachtin dll.)[8]. Tanaman yang digunakan dan mengandung alkaloid adalah tembakau dan tapak liman. Tanaman biofarmaka dan atsiri merupakan salah satu tanaman yang dapat digunakan sebagai pestisida nabati. Minyak atsiri tidak hanya sebagai penolak serangga tetapi juga dapat bertindak sebagai pestisida kontak dan juga bersifat fumigan pada beberapa serangga tertentu.
Hal ini penting mengingat pestisida nabati dapat berfungsi sebagai : penghambat nafsu makan (anti feedant), penolak (repellent), penarik (atractant), menghambat perkembangan, menurunkan keperidian, pengaruh langsung sebagai racun, dan mencegah peletakkan telur [9]. Pada akhirnya fungsi yang dimiliki tersebut berpengaruh pada tingkat kerusakan daun. Hasil analisis statistik tingkat kerusakan daun pada berbagai perlakuan yang dilakukan dapat dilihat pada Tabel 9 sebagai berikut:

Tabel 8. Hasil Analisis statistik Tingkat Kerusakan Daun Sawi (Brassica juncea L.) setelah Disemprot dengan air (kontrol), daun tembakau, tapak liman, daun kayu kuning, daun sirih hijau dan pestisida kimia

\begin{tabular}{|l|r|r|r|r|r|}
\hline & $\begin{array}{c}\text { Sum of } \\
\text { Squares }\end{array}$ & df & $\begin{array}{c}\text { Mean } \\
\text { Square }\end{array}$ & $\mathrm{F}$ & Sig. \\
\hline $\begin{array}{l}\text { Between } \\
\text { Groups }\end{array}$ & 79.351 & 3 & 26.450 & .187 & .902 \\
\hline $\begin{array}{l}\text { Within } \\
\text { Groups }\end{array}$ & 1132.033 & 8 & 141.504 & & \\
\hline Total & 1211.385 & 11 & & & \\
\hline
\end{tabular}

Berdasarkan perhitungan yang tertera pada Tabel 8 dapat diketahui bahwa antara kontrol dan perlakuan pestisida nabati (daun tembakau, tapak liman, daun kayu kuning, dan daun sirih) dan dengan pestisida kimia maupun antar perlakuan sendiri diperoleh nilai signifikasi $\mathrm{P}$ sebesar 0,902 > 0,05 yang berarti tidak terdapat perbedaan tingkat kerusakan daun sawi ((Brassica juncea L.) antara perlakuan satu dengan yang lain maupun antara perlakuan pestisida nabati, kontrol dan dengan pestisida kimia. Hal ini disebabkan karena hampir semua perlakuan dan kontrol yang diberikan larva Plutella Stylostella daunnya dimakan larva sehingga rusak, berlubang-lubang atau bagian tepi digerigiti larva, kecuali pada tanaman yang disemprot dengan pestisida kimia memberikan hasil yang bagus karena Plutella Stylostella pada penyemprotan pertama langsung mati semua.

\section{Simpulan}

Berdasarkan hasil penelitian dan pembahasan, maka dapat disimpulkan sebagai berikut : 
1. Ekstrak daun tembakau ((Nicotiana tabacum), tapak liman ((Elephantopus sp.), daun kayu kuning (Arcangelisia flava L.) dan daun sirih hijau (Piper betle Linn.) dengan konsentrasi 10 persen dari ekstrak belum memberikan pengaruh nyata pada mortalitas hama Plutella xylostella, berat basah sawi ((brassica juncea 1.) dan tingkat kerusakan daun sawi (brassica juncea 1.)

2. Ekstrak daun yang berpengaruh pada mortalitas Plutella xylostella secara berurutan adalah tembakau, daun sirih, daun kayu kuning dan tapak liman. Sedangkan pada berat basah sawi (brassica juncea 1.) secara berurutan daun kayu kuning, daun sirih hijau, daun tapak liman dan daun tembakau. Sementara terhadap tingkat kerusakan daun sawi mulai yang paling kecil rusaknya secara berurutan adalah daun sirih hijau, daun tembakau, tapak liman dan daun kayu kuning.

\section{Ucapan Terima Kasih}

Penulis mengucapkan banyak terimakasih kepada Rektor Universitas Negeri Yogyakarta dan Dekan FMIPA, UNY yang telah memberkan kesempatan dan dana untuk melakukan penelitian ini.

\section{Pustaka}

[1] Syakir, M., 2011. Status Penelitian Pestisida Nabati Pusat Penelitian dan Pengembangan Tanaman Perkebunan. Seminar Nasional Pestisida Nabati IV, Jakarta 15 Oktober 2011.

[2] Kardinan, A. dan E.A. Wikardi. 1995a. Uji hayati produksi metabolit sekunder tumbuhan sebagai insektisida nabati terhadap serangga gudang. Proc. Seminar on Chemistry of Natural Products of Indonesian Plants. Unesco Universitas Indonesia.

[3] Grainge, M. and S. Ahmed. 1987. Handbook of Plants with Pest-Control Properties. A WileyInterscience Publ., New York. 470 pp.

[4] Kardinan, Agus, 2011. Penggunaan Pestisida Nabati Sebagai Kearifan Lokal dalam Pengendalian Hama Tanaman Menuju Sistem Pertanian Organik. Pengembangan Inovasi Pertanian 4(4), 2011 hal. 262-278

[5] Mujid, dkk., 2014. Uji Efektifitas Larutan Pestisida Nabati Tehadap Hama Ulat Krop pada Tanaman Kobis. Jurnal Ilmu Pertanian dan Perikanan Vol. 3 No. 1 Hal 67-72.

[6] Asmaliyah, dkk., 2010. Pengenalan Tumbuhan Penghasil Pestisida Nabati dan Pemanfaatannya Secara Tradisional, Jakarta: Kementerian Kehutanan.

[7] Sitepu, D., dan Sutikno, P., 2001, Peranan Tanaman Obat dalam Pengembangan Hutan Tanaman (The Role of Medicinal Plants on Plant on Plantaion Forest Development), Buletin Kehutanan , 2 (2), : 14-18.

[8] Siwon, F., 1982, A Pharmacognostical Study of Some Indonesian Medicine of The Family enispermaceae, Disertasi, 10, 43, Drukkij J H Pasmans B. V's Gravenhage.

[9] Setiawati, Dkk. 2008. Tumbuhan Bahan Pestisida Nabati Dan Cara Pembuatannya Untuk Pengendalian Organisme Pengganggu Tumbuhan (OPT). Prima Tani Balitsa. Bandung. 